\title{
EXISTENTIALISM IN INDIAN ENGLISH NOVEL
}

Dr. HP Singh ${ }^{* 1}$

${ }^{* 1}$ Dept. of English, K.R. (PG) College Mathura, INDIA

Abstract:

Existentialism in Indian English Novel has its roots in western philosophy. Since our civilization has been heading towards westernization, and the life of man has been tending towards modernization. It has become inevitable for man to ask himself who he is and what his relation is to the physical and social world. The modern Indian is surrounded by the forces which are commanded and controlled by existentialist dilemmas. Modern fictional hero is a split-personality or a tortured individual through whose mind the novelist points out the social or national or human conditions. Modern heroes are not only emotionally wronged but also shaken at the existential level. The problems of existence are too wide to be managed by the modern man. The modern novel portrays outsiders, foreigners, who are empty in feelings, or incapable of communication, or unable to relate themselves meaningfully to the surroundings. Thus modern's fiction in English reflects modern human predicament; life surrounded by forces of anxiety.

Keywords:

Existentialism, Indian English, Novel, philosophy.

Cite This Article: Dr. HP Singh, "EXISTENTIALISM IN INDIAN ENGLISH NOVEL" International Journal of Research - Granthaalayah, Vol. 3, No. 7(2015): 40-42.

Existentialism in Indian English Novel has its roots in western philosophy. Since our civilization has been heading towards westernization, and the life of man has been tending towards modernization. It has become inevitable for man to ask himself who he is and what his relation is to the physical and social world. The modern Indian is surrounded by the forces which are commanded and controlled by existentialist dilemmas. Modern fictional hero is a splitpersonality or a tortured individual through whose mind the novelist points out the social or national or human conditions. Modern heroes are not only emotionally wronged but also shaken at the existential level. The problems of existence are too wide to be managed by the modern man. The modern novel portrays outsiders, foreigners, who are empty in feelings, or incapable of communication, or unable to relate themselves meaningfully to the surroundings. Thus modern's fiction in English reflects modern human predicament; life surrounded by forces of anxiety;

The anxiety of fate and death is most basic and most universal. Paul Tillich points out that "the anxiety of death increases with the increase of individualization and that people in collectivistic cultures are less open to this type of anxiety". Not to speak of the existentialist writers even R K Narayan could not remain indifferent to the anxiety of fate \& death. For instance, Krishna gives expression to the anxiety of fate and death when he says "There is no escape from loneliness and separation .... Wife, child, brothers, parents, friends...... We come together only to go apart again. It is one continuous movement. They move away from us as we move away from them, 


\section{INTERNATIONAL JOURNAL OF RESEARCH -GRANTHAALAYAH \\ A knowledge Repository}

Social

the law of life cannot be avoided. The law comes into operation the moment we detach ourselves from our mother's womb. All struggle and misery in life is due to our attempt to arrest this law or get away from it". A profound loneliness is the only truth of life. The Indian novelists in English, especially the existentialist one, points out that man in every civilization is anxiously aware of the threats of nonbeing and needs the courage to affirm himself in spite of it.

Amita Desai is known for her repeated emphasis on the problems of existence. There is a halo of gloom and despair round what she writes. For instance, Gautam and Maya are subjected to uneasiness owing to their consciousness of death and fate. The heroines as well as the hero are haunted by the visions of death and fate. Both death and fate loom large in the novels which are primarily concerned with the problems of existence and the dilemmas of life.

Even a novelist like Mulk Raj Anand Shows how spiritual emptiness has come to sway the life of the modern man. Mohan casts very apt appreciation on Mrs Maninwering and her class. That has a casts system more rigide than ours. "A woman whose husband earns twelve hundred rupees a months will no leave cards at the house of woman whose husband earns five hundred. And the woman whose husband earns five hundred look down upon the woman whose husband earns three hundred, The rich do not really want to mix with each other" Anand finds a definite want of spiritual wealth in the life of the rich who have satisfaction in spending, enjoying, making love, having sex and trafficking in unlawful gratification.

Modern life is lived in the midst of meaninglessness. The modern novelist holds a mirror to life: He describes what he sees in the life of the people of his age. For instance, Bhabani Bhattacharya holds that meaning of modern life is limited to the satisfaction of hunger, Kajoli had a meaning of a life. But those who exploited and oppressed her found life meaningless. Lust made then blind to the meaning of life and as soon as their lust was satisfied, they felt that they were no better than hollow man. The modern novel in English is wide awake to the sentiment of meaninglessness. Life has no meaning, what man does is meaningless, and what he aspires for is equally meaningless. The anxiety of guilt is present in every moment of moral self- awareness and can drive man towards complete self-rejection, to the feeling being condemned - not to an external punishment but to the despair of having lost his destiny. The feeling of self-rejection or of self- condemnation is given enough expression in the Indian novel in English.

Thus, the modern Indian Novel in English investigates institutions and their meaning in relation to man life. man in relation to his own life, man in relation to his connection with the members of his family, man relation to his dealings with members of his society, man in relation to his activities in the political filed, man in relation to his actions in the economic sphere, man in relation to his religious faith and man in his relation to his norms of morality are the factors which determine man's life in its various aspects. The modern Indian novelist in English has noticed the mode of Indian life coming under the pressure of western one. Indian fiction in English has explored in the recent times, the torments of individuals and has articulated the existentialism of contemporary Indian life. Man, the Indian, feels that life with its links with other spheres of existence in meaningless. The modern Indian is in search of that which does not 


\section{INTERNATIONAL JOURNAL OF RESEARCH -GRANTHAALAYAH

exist. He is indifferent to what he possesses. He falls in the ocean of existential phenomenon which hardly has any value, any meaning, and any reality. Existentialism is, in a word, a mere mirage.

\section{REFERENCES}

[1] Paul Tillich, The courage to be. (New Haven yale university press, 1952, Page 42.)

[2] R K Naryan The English Teacher (Mysore: Indian Thought Publication,1989 Page . 218) [3] Muylk Raj Anand, Coolie Page 314.

[4] Bhabani Bhattacherya, SO Many Hungers. 1978 